\title{
Na sledi zgodnjebronastodobne poselitve v dolini Rižane Arheološke raziskave na najdišču Ključ
}

\author{
Manca Vinazza, Oddelek za arheologijo, Filozofska fakulteta, Univerza v Ljubljani \\ Matej Draksler, Skupina STIK
} $<$

V članku predstavljamo najdišče Ključv dolini Rižane. Na podlagi tehnološke in tipološke analize keramike opredeljujemo najdišče v zgodnjo bronasto dobo. Ključno vlogo pri izbiri lokacije najdišča je domnevno odigrala bližina vode in prometna povezava pod Kraškim robom oz. Podgorskim Krasom, ki povezuje Tržaški zaliv in Istro po kopnem. V neposredni bližini Ključa poznamo le eno sočasno najdišče, Jama nad Brežcem, kar je po našem mnenju posledica stanja raziskav.

Ključne besede: zgodnja bronasta doba, nižinska naselbina, dolina Rižane, Ključ, kaštelir

In this article we present lowland type of settlement Ključ in Rižana valley. Due to technological and typological pottery analysis, we are able to date this site to Early Bronze Age. Nearby fresh water and communication route under Karts Edge, which connects Gulf of Trieste and Istria, were presumably the main reasons for selecting Ključ as a location. There is only one other known contemporaneous site nearby Ključ - cave Jama nad Brežcem. We believe this is only a consequence of the state of research.

Keywords: Early Bronze Age, lowland settlement, Rižana river valley, Ključ, hillfort

V prispevku predstavljamo arheološko najdišče Ključ v dolini reke Rižane, kjer so leta 2014 potekale arheološke raziskave, ki so kljub skromnemu obsegu pomembno prispevale $\mathrm{k}$ poznavanju tega prostora $\mathrm{v}$ bronasti dobi.

Arheološko najdišče Ključ se nahaja na nižji vzpetini, ki leži na stičišču treh pokrajin, Podgorskega Krasa (Kraški rob), Brega (Bržanija) in doline Rižane. Podgorski Kras ima apnenčasto osnovo, a so se kraške oblike tu slabo razvile. Prehod v flišno pokrajino Slovenske Istre namreč ni nenaden. Pod stenami (stopnjami), ki so nastale kot posledica součinkovanja tektonskih in erozijskih procesov, se vleče razmeroma položno pobočje, ki je le v osrednjem delu prekrito z debelejšimi sloji flišnih kamnin, medtem ko je v zgornjem delu, bliže stenam, takoj pri vrhu še apnenec ali debela plast grušča, pomešane- ga $\mathrm{z}$ rdečerjavo kraško prstjo. Ta predel predstavlja izrazito prehodno pokrajino, ki se začne $\mathrm{v}$ občini Dolina na italijanski strani in se razteza od Socerba, Ospa, Gabrovice, Črnega Kala, Loke, Bezovice do Podpeči. Medtem pa nižje, od Dola nad Hrastovljami do Sermina poteka dolina reke Rižane s ploskim dnom, ki je pri Dolu in Hrastovljah prekrito $\mathrm{z}$ debelimi sloji flišnih naplavin. V njenem zgornjem delu, od Dola do izvira Rižane, gre za suho dolino Rižane. Danes teče od Hrastovelj le potok hudourniškega značaja, ki poleti praviloma presahne.

Reka Rižana danes izvira v Zvročku, manj kot kilometer stran zračne linije severozahodno od Ključa. Dolina je med Dolom in Hrastovljami ozka in globoka, pri izviru Rižane pa se na široko odpre v rahlo valovito ravnico. Prav na tem mestu leži obravnavano najdišče Ključ. Del doline pri izviru je iz eocenskih apnencev, ves preos- 


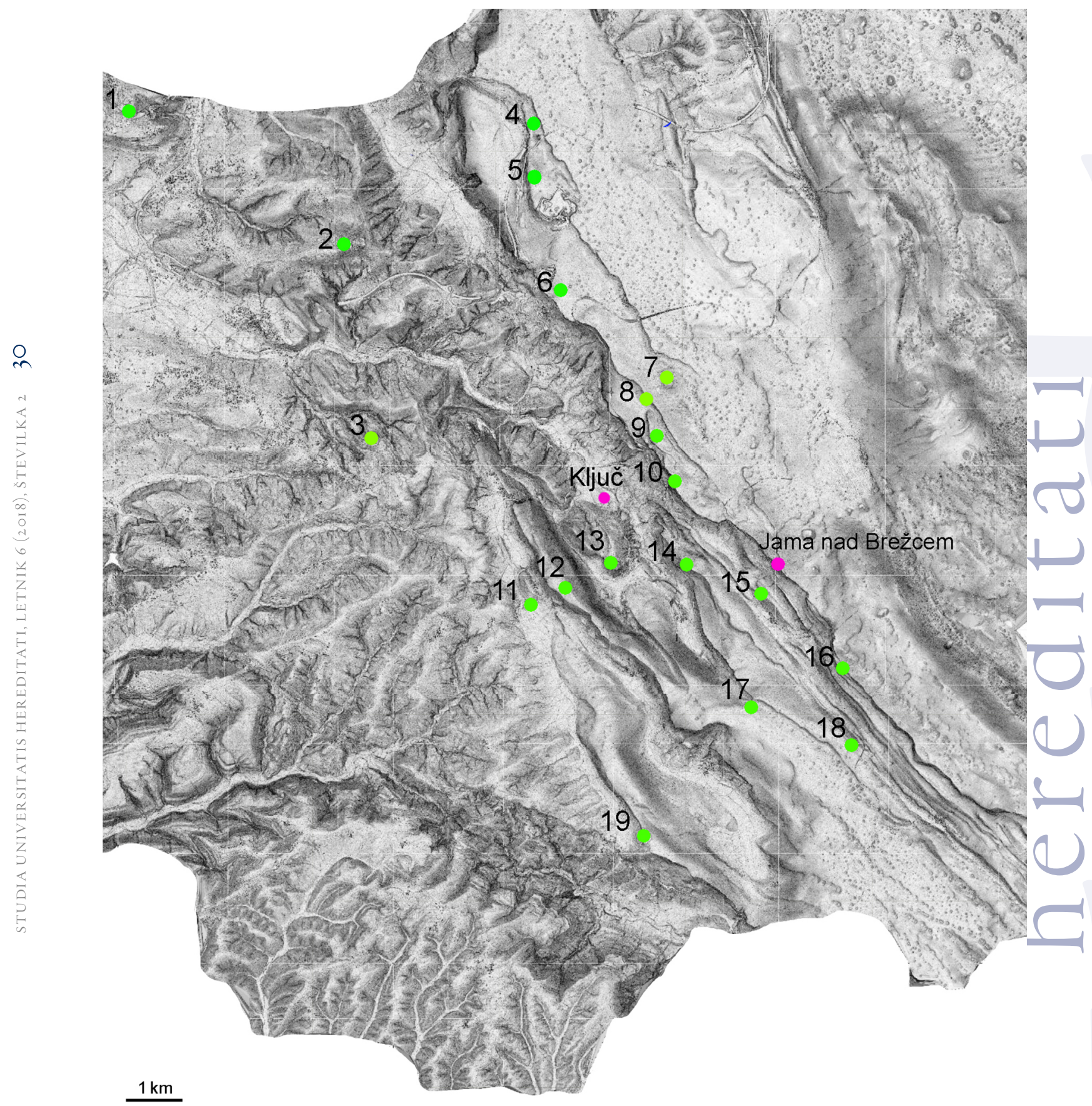

Slika I. Lega zgodnje bronastodobnih najdišč Ključ in Jama nad Brežcem (magenta) ter kaštelirji (zelena) (prirejeno po RKD pregledovalniku). I. Jelarji, 2 Tinjan, 3.Sv. Anton, 4. Kastelec (Varda), 5. Kastelec (Hrib), 6. Črnotiče (Mozar), 7. Črnotiče (Marija Snežna), 8. Bezovica (Stena), 9. Bezovica (Brgode), Io. Podpeč pri Črnem Kalu, II. Gračišče (Griža), 12. Gračišče (Lačna), 13. Hrastovlje (Vrh), 14. Zaningrad (Kovk), 15. Zazid (Zjat), 16. Zazid (Mojbrma), 17. Dol pri Hrastovljah (Gradež), 18. Zazid (Na Krasu), 19. Sočerga (Sv. Kvirik). 
tali del pa iz flišnih kamnin, med katerimi je najbolj pogost lapor (Šiškovič I990, 9-I2).

\section{Zgodovina raziskav}

Kraški rob je skupaj z Bržanijo imel od nekdaj strateški pomen. Tu se namreč ločuje flišna Istra in apnenčast Kras, v širšem smislu Sredozemlje in celina. Na tem stiku so že v prazgodovini stala gradišča oz. kaštelirji (slika I; npr. Mali Kras severno od Socerba, Grad na Socerbu, gradišče nad Prebenegom, Hrib nad Kastelcem, Mozar nad Črnim Kalom, Gradišče (Marija Snežna) pri Prapročah, Stena nad Loko, Brgode, gradišče nad Podpečjo, Kovk nad Zanigradom in Gradež nad Movražom), ki so nadzorovali poti iz notranjosti celine oz. Tržaškega zaliva na istrski polotok (Zupančič 1990, 19; Gorenc 2006, 98).

Arheološko najdišče Ključ (slika I) prvič omenja že Alberto Puschi (Benussi 1927-1928, 261; Truhlar 1975, 129), prve arheološke raziskave pa so tu potekale šele leta $2014^{1}$, in sicer na parc. $42 \mathrm{I} / \mathrm{I}, 42 \mathrm{I}$ in $\mathrm{I} 407 / \mathrm{I}$, vse k. o. Loka.

$\mathrm{V}$ neposredni okolici Ključa poznamo več najdišč iz različnih obdobij, saj gre za izrazito prehoden in zato strateško pomemben prostor. Omeniti velja predvsem večje število kaštelirjev, ki pa so večinoma opredeljeni v pozno bronasto in začetek starejše železne dobe (Register kulturne dediščine RS). Glede na analizo keramike, ki je bila odkrita pri arheoloških raziskavah na Ključu, ugotavljamo, da so najdbe starejše, natančneje iz zgodnje in/ali srednje bronaste dobe. Najdišča iz tega časa so na tem prostoru maloštevilna. Sočasne najdbam na Ključu so nekatere najdbe iz Jame nad Brežcem (Sakara Sučević 2004; slika I), medtem ko sodi bodalo iz Jernejeve jame pri Črnem kalu, ki ga je skupaj s keramiko našel B. Lonza in domnevno predstavlja naselbinsko najdbo, v srednjo oz. mlajšo bronasto dobo (Šinkovec 1995, 95, kat. št. I83). Tudi nekatera jamska najdišča in vrtače so okvirno

Predhodne arheološke raziskave v obliki arheološkega terenskega izkopa in arheološke raziskave ob gradnji je izvedla Skupina STIK, pod vodstvom Sama Hvalca in Mateja Drakslerja (oba Skupina STIK) in pod konservatorskim nadzorom Jake Bizjaka (ZVKDS, OE Piran). opredeljena v bronasto dobo (Register nepremične kulturne dediščine RS).

\section{Arheološke raziskave}

\section{Metodologija in potek raziskave}

Metodologija terenskih raziskav je bila pogojena s standardi arheoloških raziskav, predvidenih za arheološki testni izkop ${ }^{2}$. Arheološke plasti so bile izkopane ročno stratigrafsko. Dokumentacija je obsegala geodetsko, fotografsko in opisno dokumentiranje evidentiranih plasti in arheoloških ostalin.

\section{Rezultati arheološkega testnega sondiranja}

$\mathrm{Na}$ obravnavanem območju (slika 2) je bilo najprej ročno izkopanih Io testnih sond velikosti I $\times$ I m, katerih globina je segala do geološke osnove (slika 4). Slednja se je pojavila na globini med 5 in $40 \mathrm{~cm}$. V tej fazi raziskave so bili odkriti predvsem številni odlomki prazgodovinske lončenine, nekaj odlomkov rimskodobne lončenine in gradbenega materiala ter nekaj časovno neopredeljivih kosov. Na podlagi arheoloških rezultatov je bilo izkopno polje na prostoru predvidene postavitve treh pomožnih gospodarskih stavb, kasneje razširjeno. Izkopane so bile tri sonde $(\mathrm{I}-3)$, velikosti $6,3 \times 6,3 \mathrm{~m}$, skupne površine ca. $120 \mathrm{~m}^{2}$.

Arheološke raziskave so razkrile sledove prazgodovinske poselitve prostora, ki je bila izrazitejša v severozahodnem delu registrirane enote kulturne dediščine Hrastovlje - Kaštelir Ključ, kjer so raziskave potekale. Rimskodobne najdbe so bile odkrite izključno na pobočju ob vznožju vzpetine (slika 2), in kaže na rabo tega prostora tudi v tem obdobju.

Najdišče leži v celoti na močno prepereli in razpokani apnenčevi skalni osnovi (SE roo5, SE 2004, SE 3003; slika 4). Na razgibani podlagi je $z$ naravnimi in antropogenimi procesi nastala različno debela plast temno rumenkasto rjavega glinenega melja (SE 1002, SE 2002, SE 3002; slika 3). V tej plasti smo našli prazgodovinske najdbe, ki so bile najštevilnejše v razpokah in kotanjah apnenca. Površje se je v zad-

\footnotetext{
Pravilnik o arheoloških raziskavah (Ur. l. RS št. 3/2013).
} 


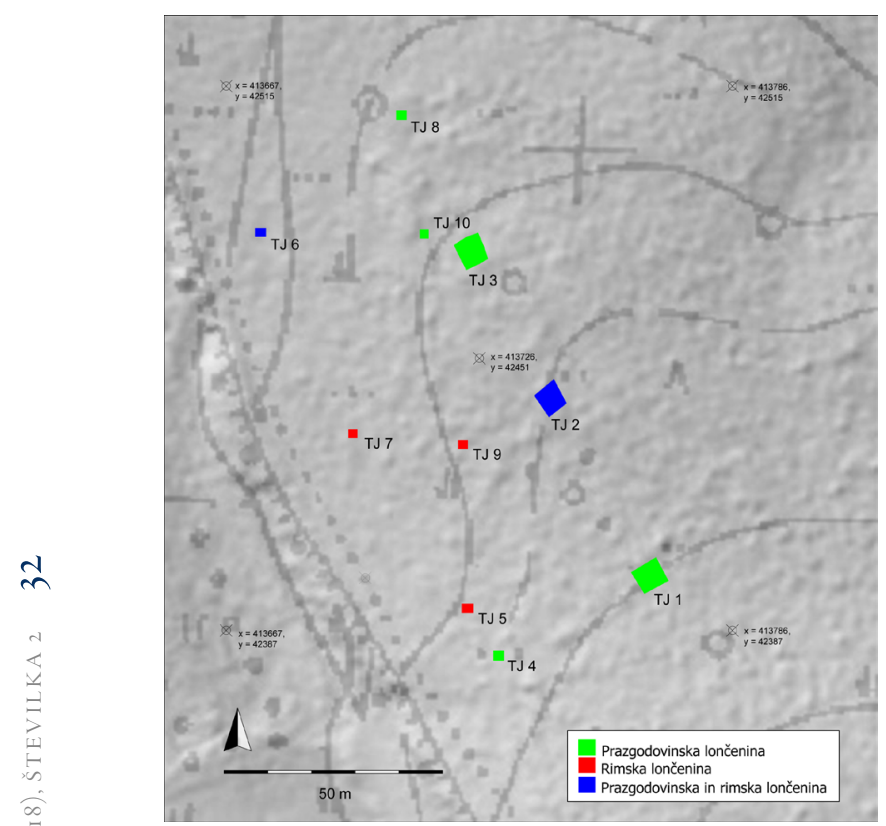

Slika 2. Ključ, lega testnih sond (prirejeno po RKD pregledovalniku ).

njih tisočletjih precej spremenilo, na eni strani $s$ kemičnimi procesi v skalni podlagi, na drugi pa zaradi človekovega vpliva, ki je z uporabo prostora (travnišvo, pašništvo idr.) vzpetino na Ključu razgalil in s tem povzročil denudacijo površja. Morebitne uporabne površine, ki bi jih lahko $\mathrm{v}$ povezavi s prazgodovinskimi najdbami pričakovali, so bile zato uničene oz. odstranjene. Pri izkopavanju sonde 3 je bila najdena večja koncentracija prazgodovinske lončenine, ožgane gline ter glinenega ometa, kar nas napeljuje $\mathrm{k}$ predpostavki, da lahko na tem delu najdišča domnevamo enega ali več prazgodovinskih objektov. V vseh treh sondah smo namreč ugotovili domnevno antropogene izravnave (npr. SE 2004; slika 5) skalne osnove (Draksler in Klasinc 201 4, 45-47).

\section{Keramično gradivo}

$\mathrm{V}$ treh sondah je bilo odkritih 743 odlomkov lončenine ( $5554 \mathrm{~g}), 6$ kosov hišnega ometa $\mathrm{z}$ vidnimi odtisi prepleta ( $132 \mathrm{~g})$, I kos železa ( $16 \mathrm{~g})$ in I živalska kost (17 g). Vse najdbe so prazgodovinske. Od tega smo za izris izbrali iz sond 24 kosov in le $\mathrm{v}$ manjšem obsegu uspeli rekonstruirali premer ustja ali dna posod, saj gre po večini za zelo majhne odlomke.

Lončenino smo obravnavali tehnološko in tipološko, saj je pri tako slabo ohranjenem keramičnem gradivu način izdelave lončenine bistveno bolj izpoveden. Način izdelave lončenine smo opazovali na makroskopskem nivoju po Horvatovi (Horvat 1999). Osnovne sestavine lončarskih mas smo ugotavljali z lupo. Za potrebe lažje predstavitve beleženja posameznih kosov smo vsak obravnavani odlomek fotografirali pod stereo lupo (Leica ES 2 - Stereo microscope; slika 6), pri čemer je potrebno izpostaviti, da gre pri fotografiji zbruska za namen osnovnega prikaza, in da smo pri ugotavljanju sestavin opazovali tudi druge dele odlomka.

Lončenina je $\mathrm{z}$ vidika načina izdelave zelo enotna. Izdelana je prostoročno. Prevladujejo finozrnate mase (velikost zrnc 0,25 do $0,50 \mathrm{~mm}$ ) (19 odlomkov oz. $79 \%$ ), ostalo pa so zelo finozrnate mase (velikost zrnc do o,25 mm) (4 odlomki oz. 2I \%). Ugotovili smo 8 različnih lončarskim mas (od tu dalje LM) (sliki 6-7), pri katerih gre $\mathrm{z}$ izjemo LM I, kjer smo prepoznali kamnino (A), ki ne reagira z Io \% vodno raztopino vodikovega klorida $(\mathrm{HCl})$, za mase $s$ kombinacijo sljude (C), organskih materialov (D), železovih oksidov (E), groga (G) in/ali glinenih jeder (F). Ugotavljamo odsotnost primesi kalcijevega karbonata (B). Prevladujeta dve lončarski masi (LM 5; 8 odlomkov in LM 8; 7 odlomkov; sliki 6-7), pri katerih osnovne primesi predstavljajo sljuda (C), železovi oksidi (E) in grog (G). Med seboj se ločita le po prisotnosti organskih sestavin (D).

Pri dodelavi površine prevladuje brisanje, in sicer kar v 96 \% (23 odlomkov). Na Monkodonji npr. glajenje predstavlja prevladujoč način dodelave površine, ki je zastopan v 5i \% (Hellmuth Kramberger 2017a, 42).

Od načinov žganja keramike smo ugotovili le tri. Gre za prevladujočo redukcijsko (I7 odlomkov oz. 71 \%) in nepopolno oksidacijsko žganje ( 5 odlomkov oz. 21 \%) ter redukcijsko z oksidacijsko atmosfero v končni fazi ( 2 odlomka oz. 8 


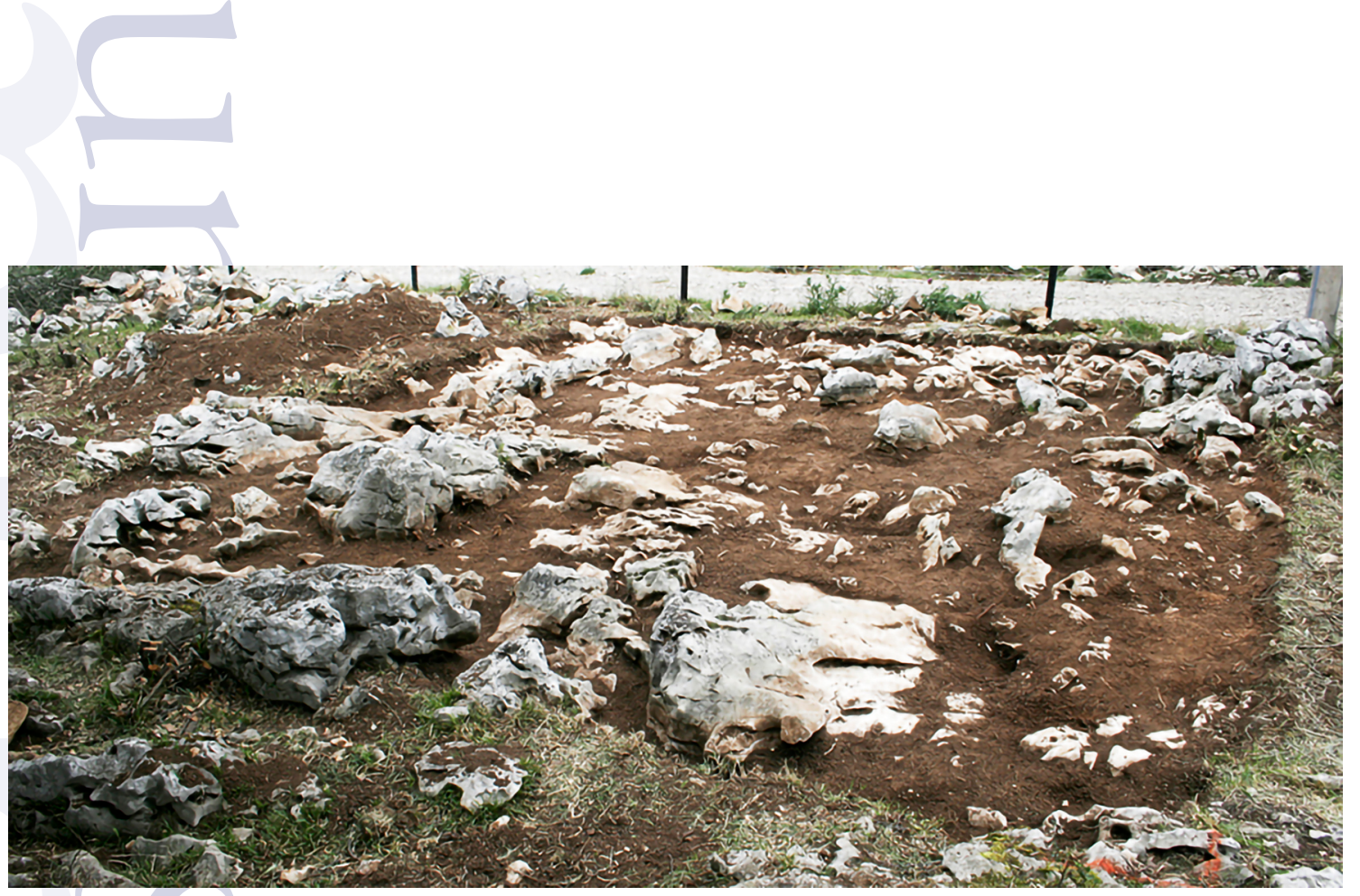

Slika 3. Ključ, pogled na glineno meljasto plast v sondi I (SE IO02), ki je prekrivala apnenčevo skalno osnovo (SE ı००5). Pogled proti severu. Foto: G. Babič.

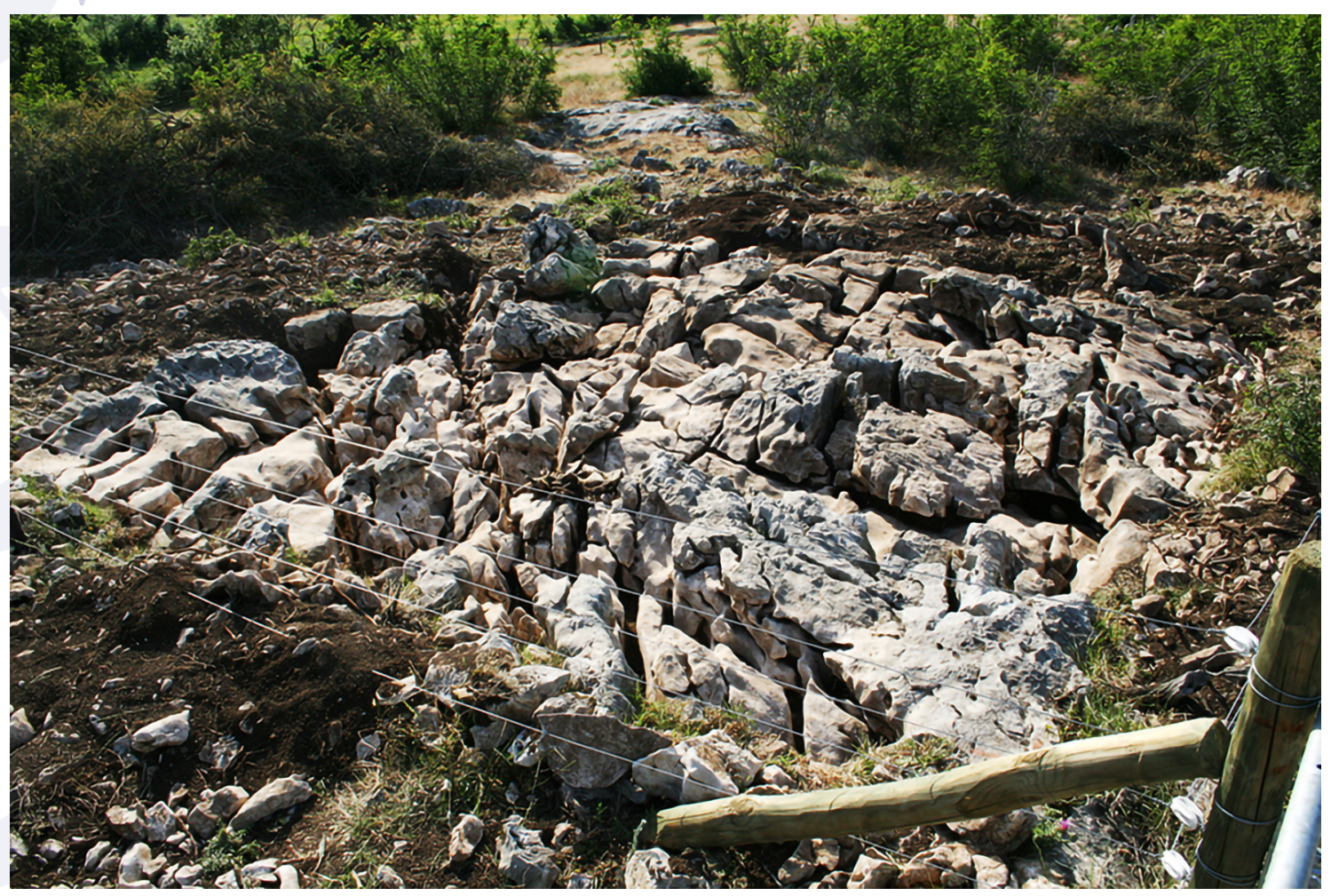

Slika 4. Ključ, apnenčeva skalna osnova v sondi 3 (SE 3003 ). Pogled proti severozahodu. Foto: G. Babič. 


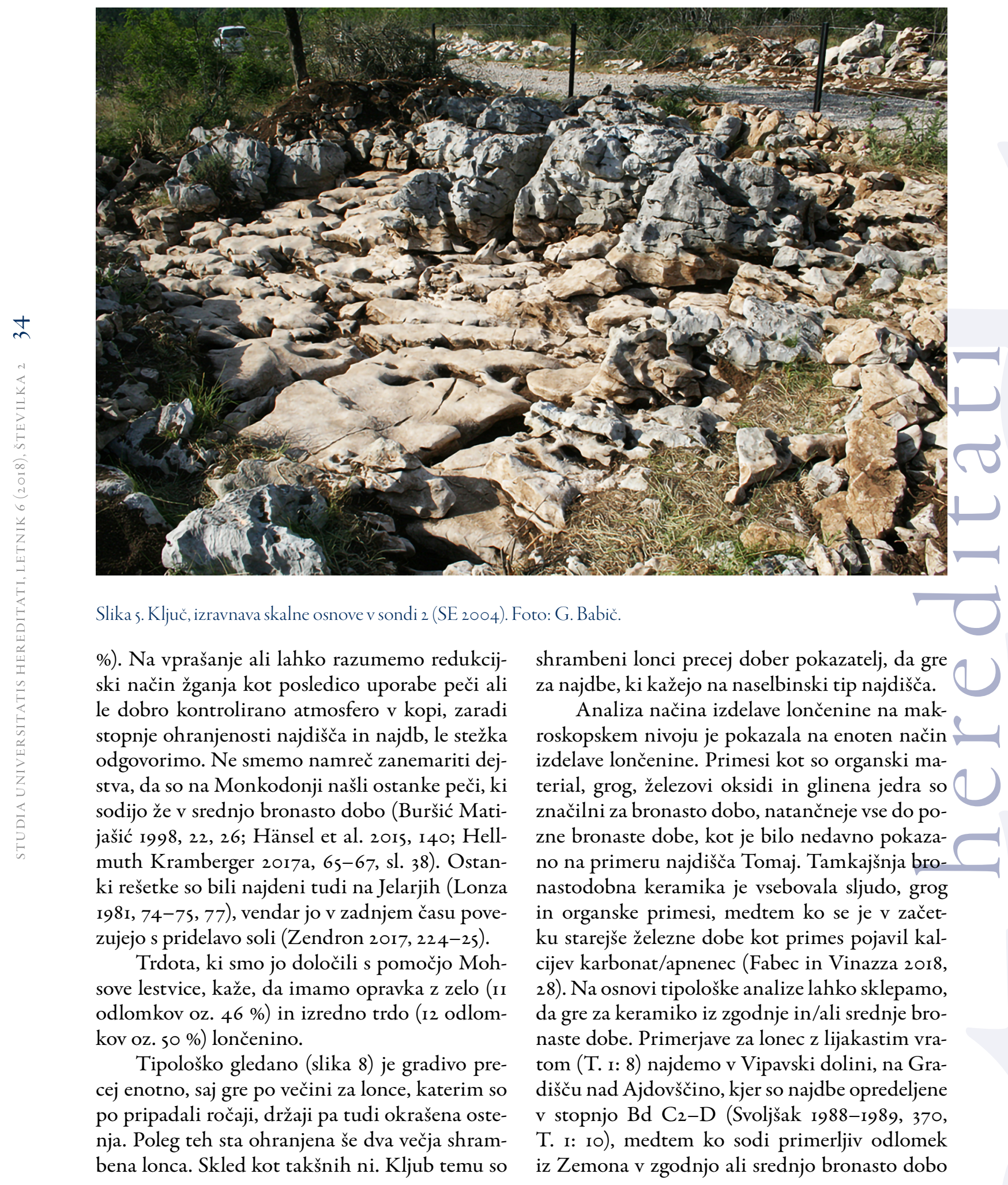




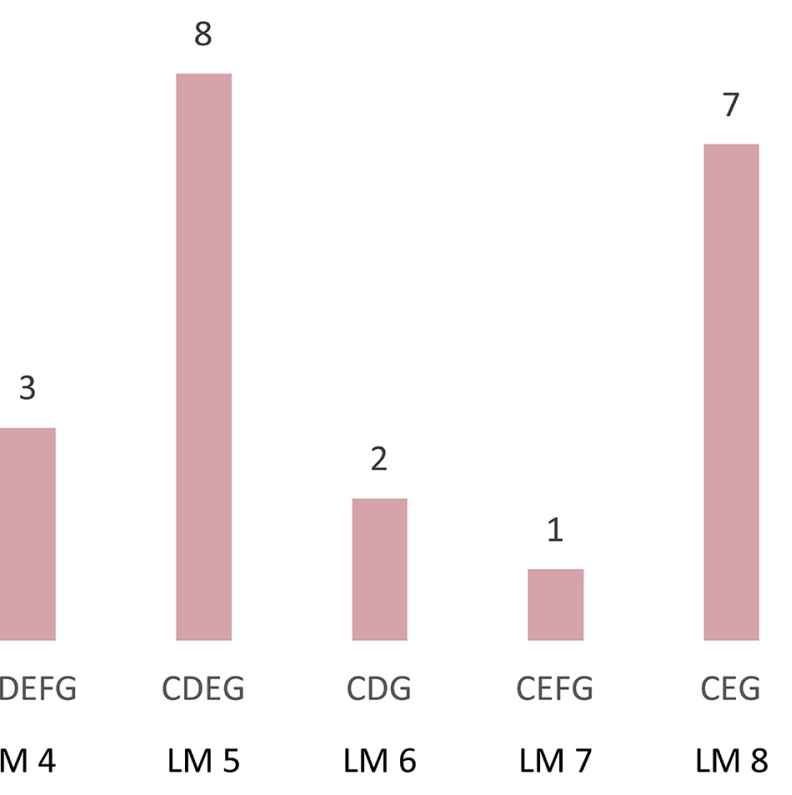

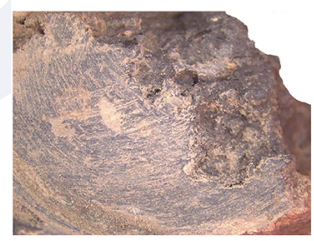

LM 1

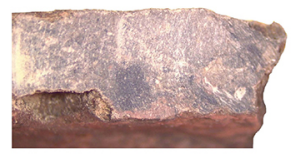

LM 5

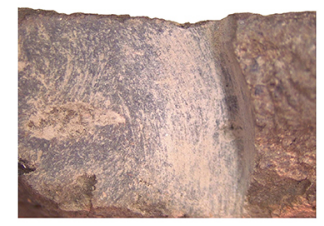

LM 2

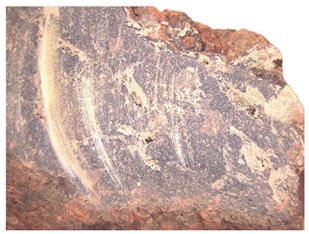

LM 6

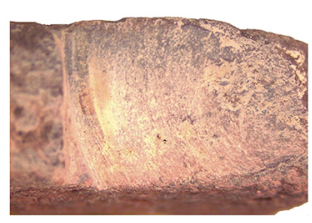

LM 3

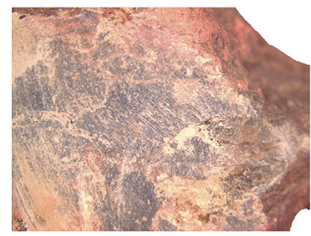

LM 7

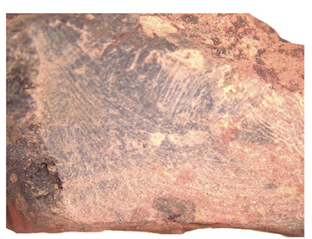

LM 4

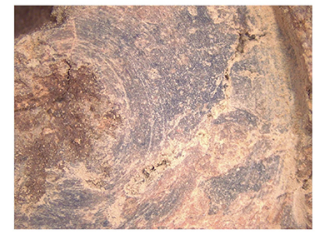

LM 8

Slika 6. Lončarske mase iz Ključa (LMI-8).

(Bratina 2014a, 566, sl. 35.4:3). Večjemu shrambenemu loncu (T. ı: 6) najdemo primerjavo na najdišču Gropi - Stari Guran v Istri, ki sodi v zgodnjo bronasto dobo (Mihovilić 2007-2008, 46, tab. 7: 73). Tudi sicer najdemo na tem najdišču več primerjav za obravnavano najdišče, kot je npr. ustje lonca (T. ı: IO) (Mihovilić 2007-2008, 46, tab. 5: 5I) ter okrašeno ostenje s rebrom (T. 2 : 2I), ki poteka vodoravno in navpično (Mihovilić 2007-2008, 46, Tab. 3: 19). Slednji motiv sreča- mo prav tako tudi v Vipavski dolini, na najdišču Log pri Vipavi, tako v gladki kot s prsti razčlenjeni obliki, opredeljen je v zgodnjo ali srednjo bronasto dobo (Bratina 201 4b, 576, sl. 36.6: 23, 25). Takšen primer iz Sermina sodi v srednjo bronasto dobo (Josipovič et al. 1997, 26, T. 30: I8; Svetličič 1997, 53). V zgodnjo ali srednjo bronasto dobo sodijo tudi lonci z rahlo izvihanim ustjem (T. I: II), s primerjavami ravno tako $\mathrm{v}$ Vipavski dolini (Bratina 2014b, 576, sl. 36.6: Io), na Monkodonji 


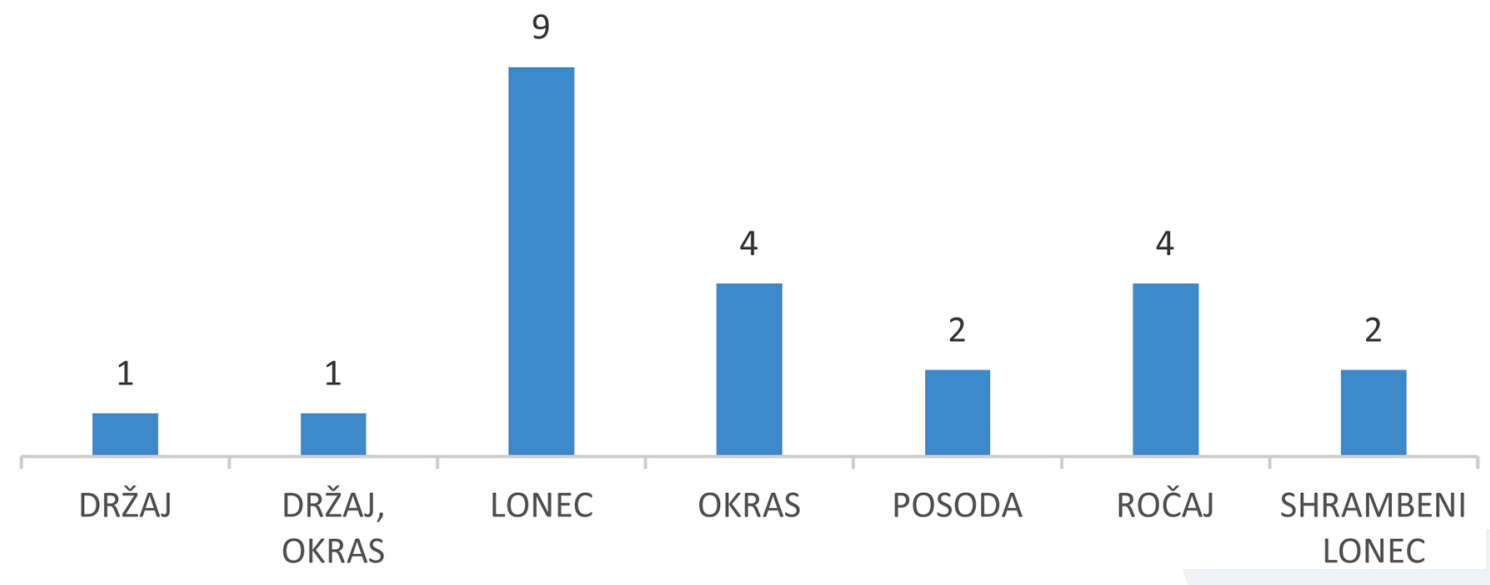

Slika 7. Število prepoznanih tipov in delov posod iz najdišča Ključ.

(Hellmuth 2017b, T. 136: 7) ter na zgodnjebronastodobnem kolišču Mali Otavnik na Ljubljanskem barju (Gaspari 2008, 65, T. 3: 6). Odlomek ustja lonca (T. I: 13) spominja na kroglaste lonce iz Jelarjev, ki so opredeljeni širše, v bronasto dobo (Lonza 198I, Tav. I4: I), medtem ko so iz Malega Otavnika zgodnje bronastodobni (Gaspari 2008, 65, T. I0: 7). Držaj z odtisom prsta (T. I: I), kakršne najdemo v jami Srđani v Istri, sodi v zgodnjo bronasto dobo (Čuka 2009, 24, T. 5: 24). Takšne držaje poznamo tudi iz jame Orehova pejca/Grotta dei Ciclami v 3. režnju, v katerem je bila najdena tako kaštelirska keramika kot zgodnja, eneolitsko/bronastodobna lončenina (Gilli in Montagnari Kokelj 1993, I59, fig. 64: 668), kar kaže torej na čas pred gradišči oz. pred srednjo bronasto dobo. Polkrožne kanelure so načeloma večinoma obdajale aplicirane bradavice (T. 2: 22), kar srečamo na Monkodonji v sondi 9, torej v času zgodnje oz. začetka srednje bronaste dobe (Hellmuth Kramberger 2017a, 322-325, 4I0; Hellmuth Kramberger 2017b, T. 19: 9). V srednjo bronasto dobo sodi okrašeno ostenje iz Ključu bližnje Jame nad Brežcem (Sakara Sučević 2004, 230, sl. 6: 7).

Tako tehnološka kot tipološka analiza keramike je pokazala na precej enoten keramični zbir. Primerjava $z$ drugimi najdišči kaže na čas zgodnje in/ali srednje bronaste dobe, vendar se predvsem na podlagi primerjav $\mathrm{z}$ najdišči kot so Gropi - Stari Guran, Monkodonja in Mali
Otavnik nagibamo, da gre za čas zgodnje bronaste dobe.

\section{Sklep}

Arheološke raziskave, izvedene na najdišču Ključ leta 20I4, so pokazale, da gre za tip poselitve, ki v dolini Rižane in pod Kraškim robom še ni bil znan. Na celotnem območju registrirane enote kulturne dediščine in njene bližnje okolice nismo uspeli odkriti sledov obrambnega sistema. Podobno lego ima tudi območje nekdanje prazgodovinske poselitve na mestu današnje cerkve sv. Trojice v Hrastovljah, ki po našem mnenju verjetno predstavlja enak tip naselbine. Čeprav skromna slika, pa v določenih potezah spominja na Vipavsko dolino z najdišči, kot sta Log in Zemono iz zgodnje oz. srednje bronaste dobe, medtem ko okoliška gradišča z izrazitimi obrambnimi zidovi ležijo na višjih legah (npr. Gradišče nad Ajdovščino in Sv. Pavel nad Vrtovinom).

Keramične najdbe iz Ključa so zelo slabo ohranjene, opravka imamo z zelo fragmentiranimi kosi. Takšno situacijo srečamo tudi na najdišču Gropi - Stari Guran v južni Istri (Mihovilić 2007-2008, 46), ki velja velja za zgodnje bronastodobno naselbino odprtega tipa, brez obzidja. Tovrstne naselbine je za območje zahodne Hercegovine kot takšne opredelil Borivoj Čović, za katere pravi, da so postavljene na terasah na manj strmih pobočjih ali na rahlo zaobljenih 
gričih, običajno nedaleč od ravnin in dolin. Zanje je značilna ohranjenost tanke kulturne plasti, sledovi stavbnih ostalin pa so vidni na površini ali v temnem humusnem sloju (Čović 1983, I 43-144; Čović 1989, 83-94; Mihovilić 20072008, 47-48; Buršić Matijašić 2oII, 65). Tudi v severni Dalmaciji se v tem času pojavljajo takšne oblike naselbin, vendar so v primerjavi s sočasnimi gradišči, maloštevilne (Batović 1990, 137; Mihovilić 2007-2008, 48). V Istri poznamo večje število takšnih, bronastodobnih najdišč v okolici Kanfanara in Limske Drage, zanesljivo v zgodnjo bronasto dobo pa sodi najdišče Japlenica $\mathrm{v}$ bližini Ližnjana (Buršić Matijašič 20II, 65-68).

Kljub temu, da je najdišče Ključ v Registru kulturne dediščine evidentirano kot kaštelir, lahko sklenemo, da najdišče nima osnovnih značilnosti gradišča. Pri tem ponovno izpostavljamo odsotnost obrambnih struktur ter nadmorsko višino najdišča, ki znaša na njenem najvišjem delu $124 \mathrm{~m}$, predel, kjer so bile izkopane sonde I-3 pa med ${ }_{10} 4$ in $109 \mathrm{~m}$. To pomeni da je vrh Ključa (I24 n. m. v.) od ravninske okolice dvignjen med 30 in $50 \mathrm{~m}$. Če primerjamo okoliške kaštelirje so njihove nadmorske višine bistveno višje, in sicer od $300-400 \mathrm{~m} \mathrm{n}$. v. (slika I). Ključ po našem mnenju predstavlja neutrjeno naselbino na neizpostavljeni lokaciji, torej gre za tip poselitve, kakršnega poznamo v Istri, Dalmaciji in Hercegovini pod izrazom zunajgradiščne naselbine. O sami funkciji tovrstnih naselbin lahko le domnevano, čeprav se nam trenutno zdi edina smiselna razlaga sezonska oblika poselitve.

Ta tip naselbin je zaradi svoje lege in odsotnosti obrambnega sistema bistveno težje prepoznati kot kaštelirje oz. gradišča. Morda prav zato v neposredni bližini Ključa in celotni dolini Rižane ter pod Kraškim robom beležimo le eno sočasno najdišče, to je jama pod Brežcem (Sakara Sučević 2004). Zagotovo so takratni prebivalci Ključa izkoristili tudi bližino vode, izvir Rižane in lego ob poti, ki je povezovala Tržaški zaliv in Istrski polotok. $V$ tem smislu razumemo tudi Kraški rob kot markantno geografsko značilnost, ki je služila za orientacijo v prostoru.
Arheološke raziskave na najdišču Ključ so pokazale, da gre za naselbino brez zidane obrambne gradnje na blago dvignjeni legi v dolini, brez obrambnih struktur nad dolino. Poselitev so najverjetneje pogojevali različni doslej ugotovljeni dejavniki, kot je bližina vode (izvir Rižane), rodovitna zemlja (flišne naplavine v dolini) in prehodnost prostora (povezava med $\mathrm{Tr}$ žaškim zalivom in Istro). Trenutno gre za edino tovrstno najdišče iz zgodnje bronaste dobe na tem prostoru. Podobno najdišče pričakujemo tudi na območju cerkve sv. Trojice v Hrastovljah, saj je današnja slika najdišč iz tega časa najverjetneje le posledica stanja raziskav.

\section{Katalog najdb}

\section{Sonda I, SE 1002}

I. Odlomek ostenja z okrašenim držajem. Sestava: zelo finozrnata (LM 2); dodelava površine: glajenje; okras: odtisi prstov; žganje: redukcijsko; izredno trda; barva: zunanja in notranja površina temno siva (IOYR 4/I). Vel. 5,I $\times 3,6 \mathrm{~cm}$.

2. Odlomek ostenja z okrašenim držajem. Sestava: finozrnata (LM 2); dodelava površine: brisanje; okras: odtisi prstov; žganje: redukcijsko; izredno trda; barva: zunanja površina rdečkasto rjava ( $5 \mathrm{YR}$ 4/4), notranja zelo temno siva ( $\left.\mathrm{IOYR}_{3} / \mathrm{I}\right)$. Vel. $5,4 \times 2,9 \mathrm{~cm}$.

3. Odlomek ostenja z ročajem. Sestava: finozrnata (LM 5); dodelava površine: brisanje; žganje: redukcijsko; izredno trda; barva: zunanja površina močno rjava $\left(7.5 Y R_{5} / 6\right)$, notranja zelo temno siva (IoYR $3 / \mathrm{I}$ ). Vel. $6.6 \times 4,5 \mathrm{~cm}$.

4. Odlomek ročaja. Sestava: finozrnata (LM 4); dodelava površine: brisanje; žganje: redukcijsko; zelo trda; barva: zunanja površina rdeča $(2.5 \mathrm{YR} 4 / 6)$, notranja zelo temno siva $\left(7.5 \mathrm{YR}_{3} / \mathrm{I}\right)$. Vel. 2,6 × 2,3 cm. Sonda 2, SE 2002

5. Odlomek ostenja z ročajem. Sestava: finozrnata (LM 2); dodelava površine: brisanje; žganje: redukcijsko; zelo trda; barva: zunanja površina temno sivkasto 


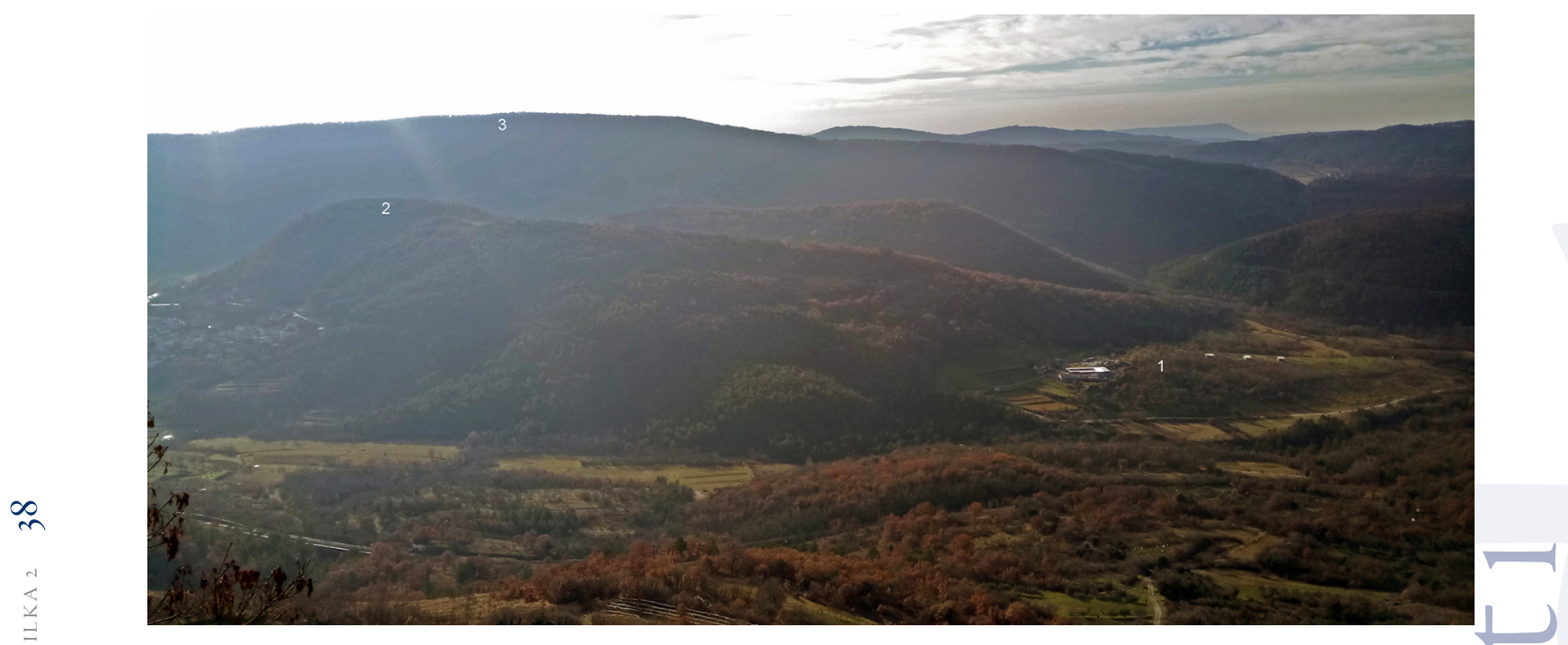

Slika 8. Arheološko najdišče Ključ (I) z Vrhom (2) in Lačno (3) v ozadju.

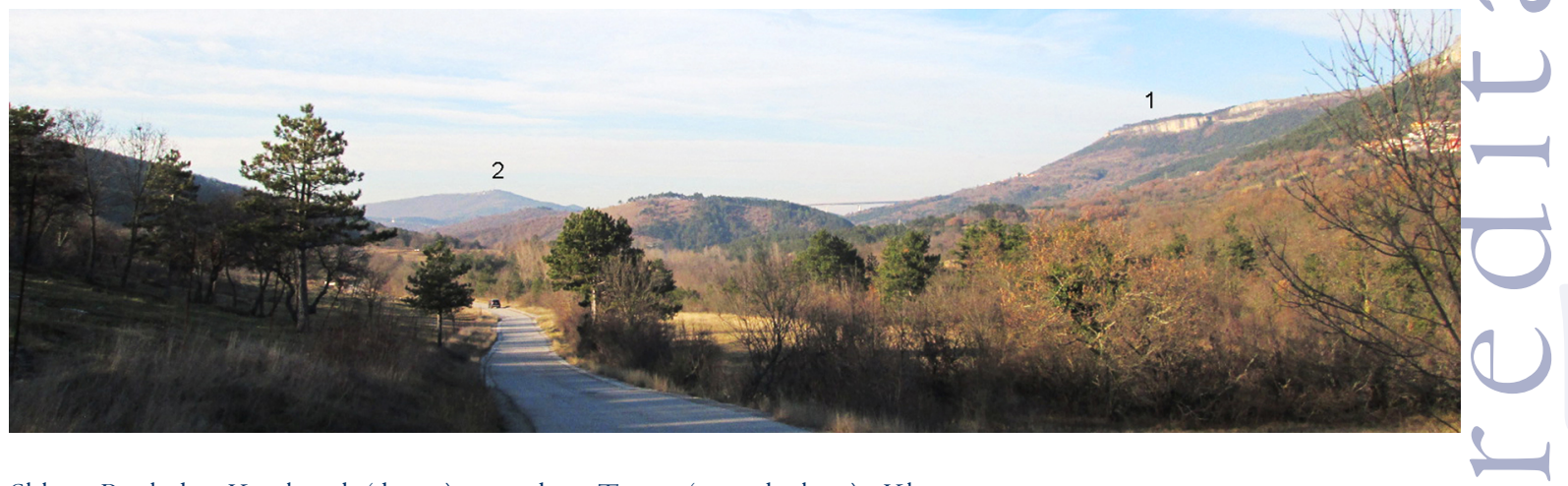

Slika 9. Pogled na Kraški rob (desno) in gradišče Tinjan (v ozadju levo) s Ključa.

rjava (IoYR 4/2), notranja rumenkasto rdeča $\left(5 Y R{ }_{4} / 6\right)$. Vel. 5, I $\times 3,1 \mathrm{~cm}$.

Sonda 3 , SE 3002

6. Odlomek ustja shrambenega lonca.

Sestava: finozrnata (LM 7); dodelava površine: brisanje; žganje: redukcijsko, v končni fazi oksidacijsko; izredno trda; barva: zunanja in notranja površina močno rjava (7.5YR 5/6). Vel. II,O × 5,6 cm.

7. Odlomek ustja shrambenega lonca. Sestava: zelo finozrnata (LM 5); dodelava površine: brisanje; žganje: redukcijsko; zelo trda; barva: zunanja površina rumenkasto rjava (IoYR 5/4), notranja rumenkasto rdeča $(5 Y R 4 / 6)$. Vel. 5,9 $\times 4,7 \mathrm{~cm}$.
8. Ustje lonca. Sestava: zelo finozrnata (LM 7); dodelava površine: brisanje; žganje: nepopolno oksidacijsko; zelo trda; barva: zunanja površina rjava (7.5YR 4/4), notranja temno sivkasto rjava ( IOYR $_{4} / 2$ ). Rek. premer ustja 24,6 cm, ohr. viš. $6,5 \mathrm{~cm}$.

9. Odlomek ustja lonca. Sestava: finozrnata (LM 2); dodelava površine: brisanje; žganje: redukcijsko; zelo trda; barva: zunanja površina rumenkasto rjava (IoYR 5/4), notranja rjava (7.5YR 4/4). Rek. premer ustja $\mathrm{I} 2,4 \mathrm{~cm}$, ohr. viš. $4,0 \mathrm{~cm}$.

Io. Odlomek ustja lonca. Sestava: finozrnata (LM I); dodelava površine: brisanje; žganje: redukcijsko; zelo trda; barva: zunanja in 
notranja površina temno rumenkasto rjava (IOYR 4/4). Vel. 2,8 × 2,7 cm.

II. Odlomek ustja posode. Sestava: zelo finozrnata $\left(\mathrm{LM}_{3}\right)$; dodelava površine: brisanje; žganje: nepopolno oksidacijsko; izredno trda; barva: zunanja površina rjava (7.5YR 4/4), notranja rumenkasto rdeča (5YR 5/6). Vel. $3,3 \times 3,4 \mathrm{~cm}$.

I2. Odlomek ustja lonca. Sestava: finozrnata (LM 7); dodelava površine: brisanje; žganje: redukcijsko; izredno trda; barva: zunanja površina rumenkasto rjava (IoYR $5 / 4)$, notranja temno siva (IoYR 4/I). Vel. $5, \mathrm{I} \times 3,4 \mathrm{~cm}$.

I3. Odlomek ustja lonca. Sestava: finozrnata (LM 2); dodelava površine: brisanje; žganje: nepopolno oksidacijsko; zelo trda; barva: zunanja površina rdečkasto rumena (7.5YR 6/6), notranja temno sivkasto rjava ( IOYR $_{4} / 2$ ). Vel. 2,9 $\times 2,5 \mathrm{~cm}$.

I4. Odlomek ustja lonca. Sestava: finozrnata (LM 5); dodelava površine: brisanje; žganje: redukcijsko; izredno trda; barva: zunanja in notranja površina močno rjava (7.5YR 5/6). Vel. 3,6 × 2,2 cm.

15. Odlomek ustja posode. Sestava: finozrnata (LM 2); dodelava površine: brisanje; žganje: redukcijsko; zelo trda; barva: zunanja površina rumenkasto rdeča ( $5 \mathrm{YR}$ $5 / 6)$, notranja sivkasto rjava (IOYR $4 / 2$ ). Vel. $1,5 \times 2,1 \mathrm{~cm}$.

16. Odlomek ustja lonca. Sestava: finozrnata ( $\mathrm{LM}_{7}$ ); dodelava površine: brisanje; žganje: redukcijsko; zelo trda; barva: zunanja površina rumenkasto rjava (IOYR $5 / 4)$, notranja rumenkasto rdeča $(5 \mathrm{YR}, 5 / 6)$. Vel. $3,3 \times 2,9 \mathrm{~cm}$.

17. Odlomek dna lonca. Sestava: finozrnata (LM 2); dodelava površine: brisanje; žganje: redukcijsko, v končni fazi oksidacijsko; izredno trda; barva: zunanja in notranja površina močno rjava $(7.5 \mathrm{YR}$ 5/6). Rek. premer dna Io,8 cm, ohr. viš. 2,8 $\mathrm{cm}$.
18. Odlomek dna lonca. Sestava: finozrnata (LM 2); dodelava površine: brisanje; žganje: nepopolno oksidacijsko; trda; barva: zunanja površina rumenkasto rdeča ( 5 YR 5/6), notranja sivkasto rjava (IoYR $4 / 2)$. Vel. $6,3 \times 4,5 \mathrm{~cm}$.

19. Odlomek okrašenega ostenja posode. Sestava: finozrnata (LM 2); dodelava površine: brisanje; okras: vodoravno aplicirano rebro, razčlenjeno z odtisi prstov; žganje: nepopolno oksidacijsko; izredno trda; barva: zunanja in notranja površina rumenkasto rdeča $(5 \mathrm{YR} 4 / 6)$. Vel. $5,5 \times 6,3 \mathrm{~cm}$.

20. Odlomek okrašenega ostenja posode. Sestava: finozrnata (LM 7); dodelava površine: brisanje; okras: vodoravno aplicirano rebro, trikotnega preseka; žganje: redukcijsko; izredno trda; barva: zunanja in notranja površina močno rjava (7.5YR 5/6). Vel. 7,0 × 5,6 cm.

21. Odlomek okrašenega ostenja posode. Sestava: zelo finozrnata (LM 8); dodelava površine: brisanje; okras: vodoravno in navpično aplicirano rebro, trikotnega preseka; žganje: redukcijsko; izredno trda; barva: zunanja in notranja površina močno rjava $(7.5 \mathrm{YR} 5 / 6)$. Vel. $5,8 \times 7,5 \mathrm{~cm}$.

22. Odlomek okrašenega ostenja. Sestava: finozrnata (LM 6); dodelava površine: brisanje; okras: polkrožna kanelura; žganje: redukcijsko; izredno trda; barva: zunanja površina močno rjave (7.5 $\mathrm{YR} 5 / 6)$, notranja zelo temno siva ( IoYR $\left._{3} / \mathrm{r}\right)$. Vel. $9,2 \times 5,2 \mathrm{~cm}$.

23. Odlomek držaja. Sestava: finozrnata (LM 2); dodelava površine: brisanje; žganje: redukcijsko; zelo trda; barva: zunanja in notranja površina rumenkasto rdeča ( $5 \mathrm{YR}$ 4/6). Vel. 6,0 × 3,0 cm.

24. Odlomek ročaja. Sestava: finozrnata (LM 2); dodelava površine: brisanje; žganje: redukcijsko; zelo trda; barva: zunanja površina zelo temno siva ( $\left.\mathrm{IOYR}_{3} / \mathrm{I}\right)$, notranja rumenkasto rjava $(5 \mathrm{YR} 4 / 6)$. Vel. $4,6 \times 4,7 \mathrm{~cm}$. 

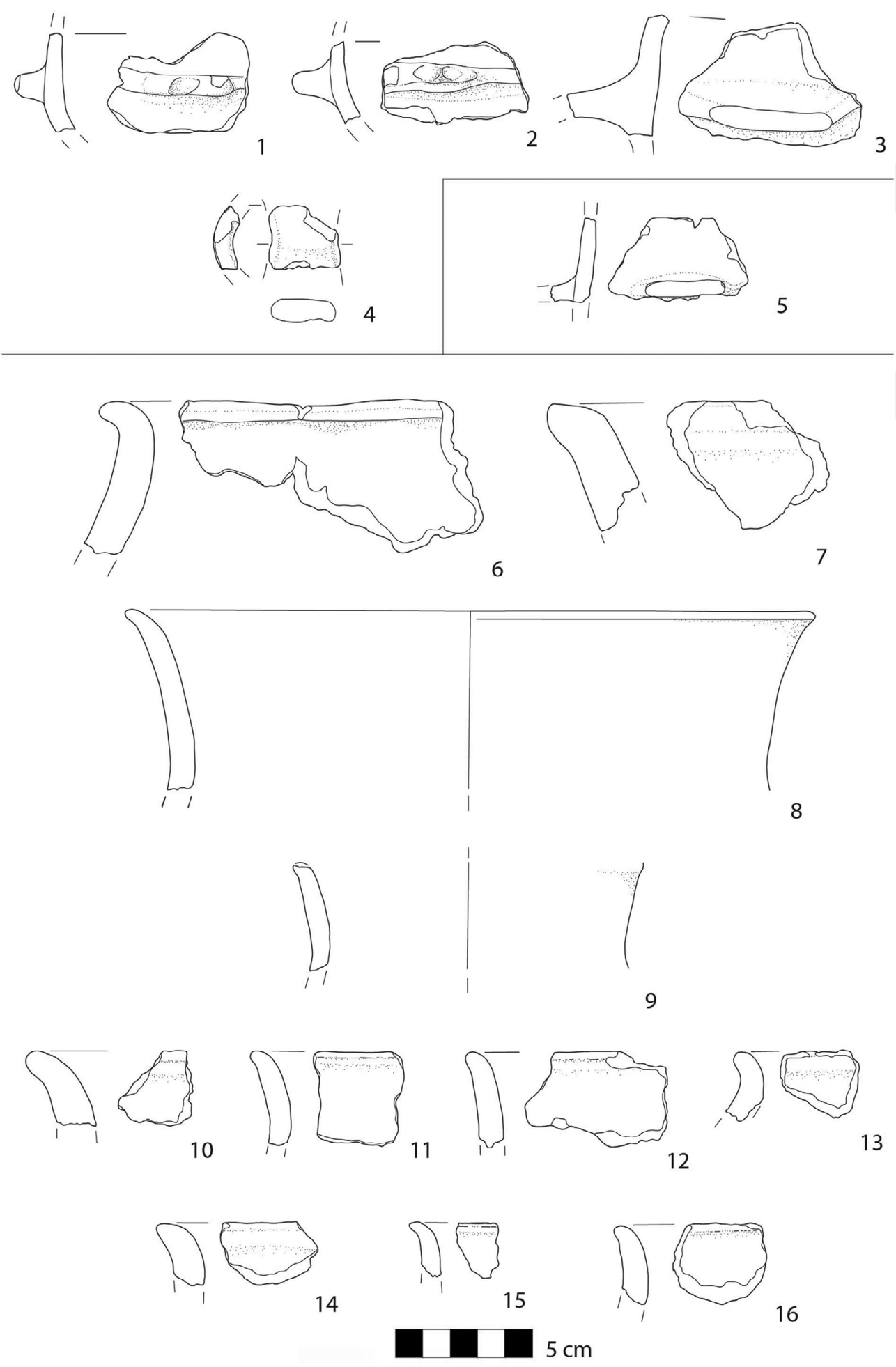

8

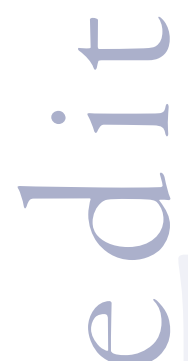

Tabla I. Hrastovlje. I-4 (sonda I), 5 (sonda 2), 6-16 (sonda 3). Vse keramika. M. = I : 2. 

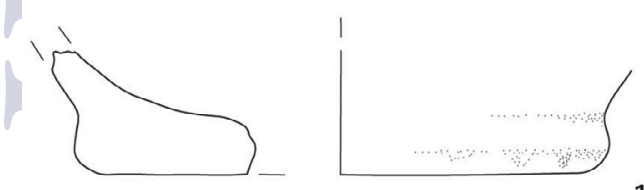

17
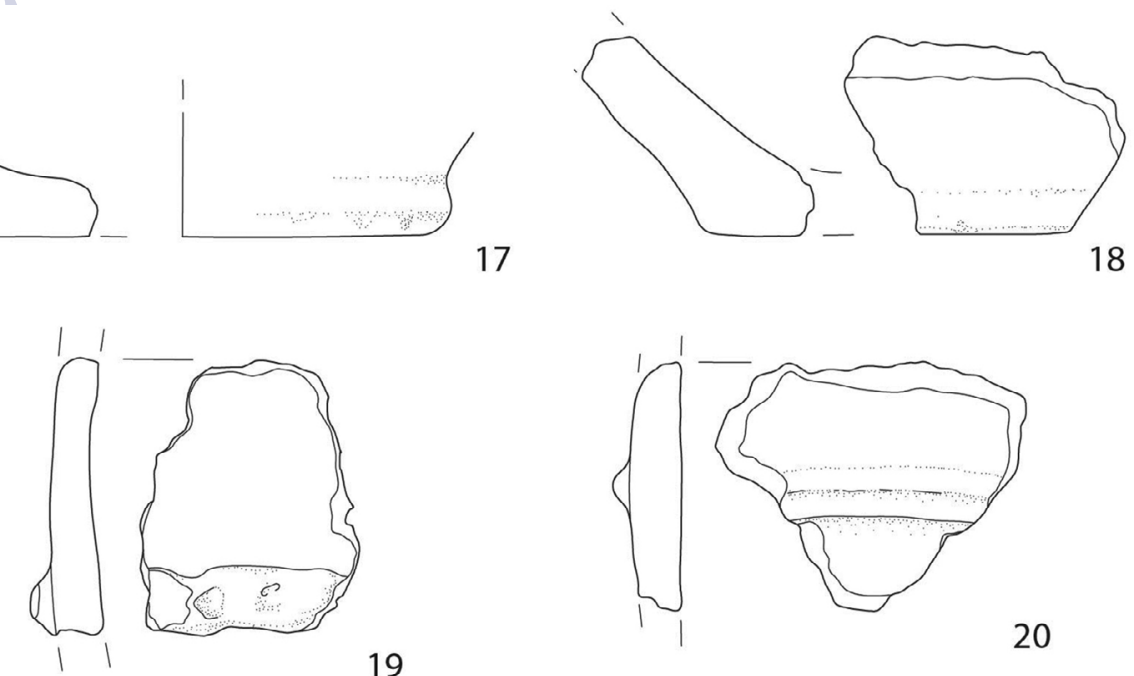

19
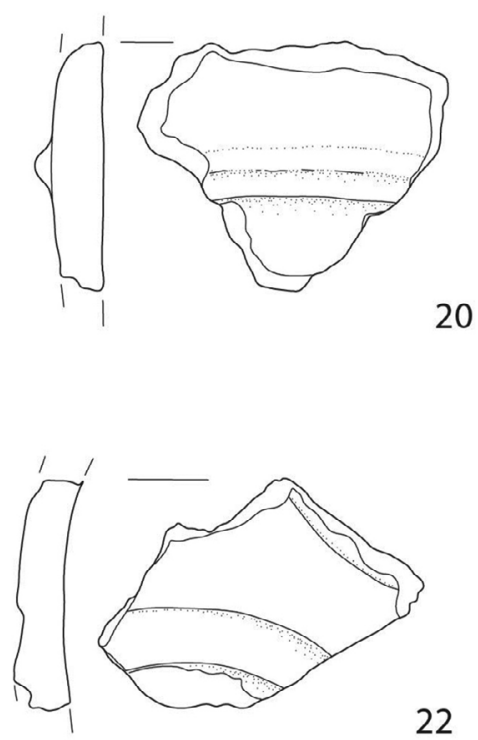

22
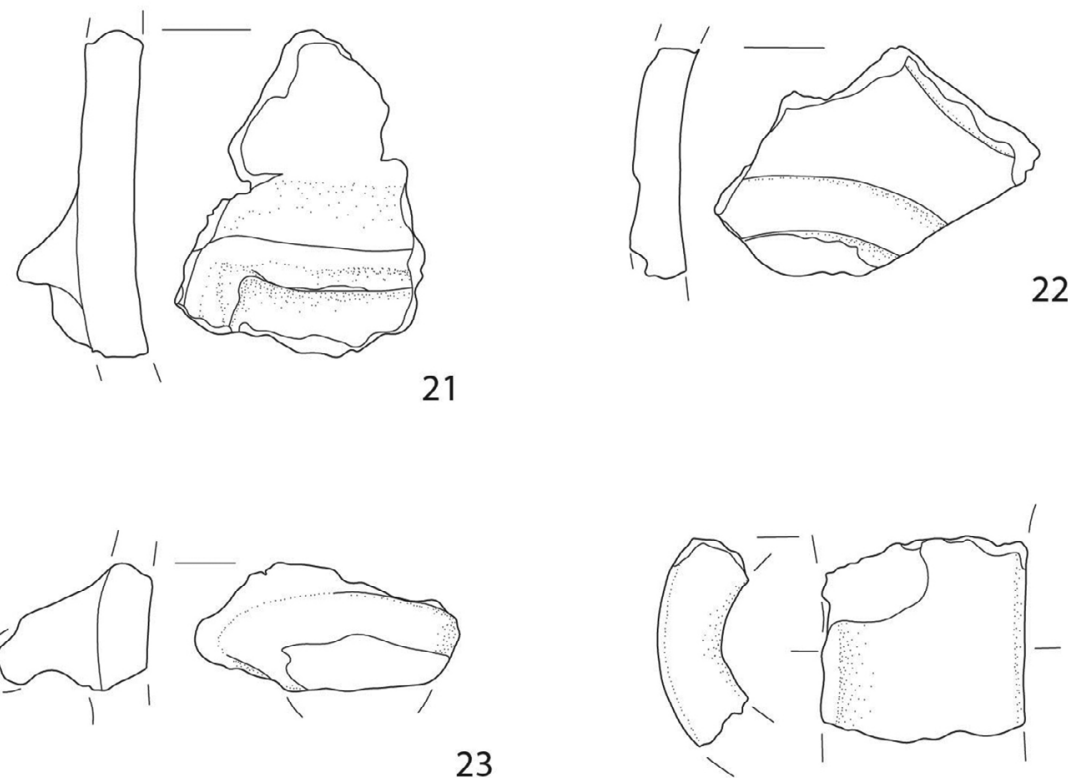

23

Tabla 2. Hrastovlje. 17-24 (sonda 3). Vse keramika. M. = I : 2. 


\section{Povzetek}

V prispevku predstavljamo arheološko najdišče Ključ v dolini Rižane. Nahaja se na nižji vzpetini, ki leži na stičišču treh pokrajin, Kraškega roba, Bržanije in doline Rižane. Kraški rob je imel skupaj z Bržanijo od nekdaj strateški pomen. Tu se ločuje Istra in Kras oz. Sredozemlje in celina. Na tem stiku so že v prazgodovini stala številna gradišča oz. kaštelirji (slika I).

Arheološko najdišče Ključ prvič omenja Alberto Puschi, prve arheološke raziskave, pod vodstvom Sama Hvalca in Mateja Drakslerja (Skupina STIK) pa so tu potekale leta 2014 , in sicer na parc. št. 42I/I, $42 \mathrm{I}$ in I407/I, vse k. o. Loka.

Najprej je bilo izkopanih Io testnih sond velikosti I $\times$ I m. Na podlagi arheoloških rezultatov je bilo izkopno polje na prostoru predvidene postavitve treh pomožnih gospodarskih stavb, kasneje razširjeno. Izkopane so bile tri sonde $(\mathrm{I}-3)$, velikosti $6,3 \times 6,3 \mathrm{~m}$, skupne površine ca. $\mathrm{I} 20 \mathrm{~m}^{2}$ (slika 2).

Izkazalo se je, da leži najdišče na močno prepereli in razpokani apnenčevi sklani osnovi (SE IO05, SE 2004, SE 3003; slika 4). Na razgibani podlagi je z naravnimi in antropogenimi procesi nastala različno debela plast temno rumenkasto rjavega glinenega melja (SE IO०2, SE 2002, SE 3002; slika 3). V tej plasti smo našli prazgodovinske najdbe, ki so bile najštevilnejše v razpokah in kotanjah apnenca. Pri izkopavanju sonde 3 je bila najdena večja koncentracija prazgodovinske lončenine, ožgane gline ter glinenega ometa, kar nas napeljuje k predpostavki, da lahko na tem delu najdišča domnevamo enega ali več prazgodovinskih objektov.

Od vseh prazgodovinskih najdb (743 kosov), smo podrobneje obravnavali 24 odlomkov. Lončenino smo obravnavali tehnološko in tipološko. Ugotovili smo, da je z vidika načina izdelave zelo enotna. Izdelana je prostoročno. Prevladujejo finozrnate mase (79\%), ostalo so zelo finozrnate (2I \%). Ugotovili smo 8 različnih lončarskih mas (LM), pri katerih gre z izjemo LM I, v kateri smo prepoznali kamnino (A), ki reagira z $10 \% \mathrm{HCl}$ raztopino, za kombinacije sljude (C), organskih materialov (D), železovih oksidov (E), groga $(\mathrm{G})$ in/ali glinenih jeder (F). Ugotavljamo odsotnost kalcijevega karbonata (B). Pri dodelavi površine je prevladovalo brisanje (96\% oz. 23 odlomkov). Določili smo tri načine žganja, in sicer redukcijsko (I7 odlomkov ali 7I \%), nepopolno oksidacijsko ( 5 odlomkov oz. 2I \%) in redukcijsko z oksidacijsko atmosfero v končni fazi (2 odlomka oz. $8 \%$ ). Keramika je zelo (II odlomkov oz. $46 \%$ ) in izredno trda (I2 odlomkov oz. 50 \%). Tipološko je gradivo zelo enotno, saj gre večinoma za lonce, ki so jim pripadali ročaji, držaji ter okrašena ostenja. Poleg teh loncev sta bila določena dva odlomka shrambenega lonca (slika 7).

Tako tehnološka kot tipološka analiza keramike kažeta na čas zgodnje in/ali srednje bronaste dobe. Primerjave za keramiko najdemo na najdiščih v Vipavski dolini, v Ljubljanski kotlini, na območju Tržaškega zaliva (jamska najdišča, gradišča) in v Istri.

Arheološke raziskave, izvedene na najdišču Ključ leta 20I4, so pokazale, da gre za tip poselitve, ki v dolini Rižane in pod Kraškim robom še ni bil znan. Ključ po našem mnenju predstavlja neutrjeno naselbino na neizpostavljeni lokaciji, torej gre za tip poselitve, kakršnega poznamo v Istri, Dalmaciji in Hercegovini pod izrazom zunajgradiščne naselbine. O sami funkciji tovrstnih naselbin lahko le domnevano, čeprav se nam zaenkrat zdi edina smiselna razlaga sezonska oblika poselitve. Trenutno gre za edino tovrstno najdišče iz zgodnje bronaste dobe na tem prostoru. V neposredni bližini Ključa in celotni dolini Rižane ter pod Kraškim robom beležimo le eno sočasno najdišče, to je jama pod Brežcem. Tako majhno število najdišč iz tega časa na tem prostoru pa je po našem mnenju le posledica stanja raziskav.

\section{Summary}

In this article, we present archaeological site Ključ in Rižana valley. It is situated on the lower rising ground, which lies at the junction of three landscapes, Karst Edge, Bržanija and Rižana valley. The Karst Edge together with Bržanija has always been of strategic importance. Here is Istria separated from the Karst or the Mediterranean from continent. We can find a lot of prehistoric hillforts (or kaštelirji) at this junction (Figure I). Alberto Puschi first mentioned archaeological site Ključ. The first archaeological research, under the leadership of Samo Hvalec and Matej Draksler (Skupina STIK), was conducted in 2014 at plot number $42 \mathrm{I} / \mathrm{I}, 42 \mathrm{I}$ and 1407 , all cadastral community Loka.

First we excavated Io testing trenches, size $\mathrm{I} \times \mathrm{I} \mathrm{m}$. Due to archaeological results we've enlarged excavation area at area of three farm buildings expected for building. We excavated 3 trenches $(\mathrm{I}-3), 6,3 \times 6,3 \mathrm{~m}$, total area of ca. I2O m2 (Figure 2). 
It turned out that site is lying on a strongly rotten and cracked limestone rock (US 1005, 2004, 3003; Figure 4). Due to natural and anthropogenic processes, different layers of dark yellow brown clayey-silty soils (US IOO2, 2002, 3002; Figure 3) were formed on this rock. In this layer we've found many prehistoric finds, most of them in limestone cracks and depressions. During the archaeological excavations of trench n. 3 , a greater concentration of prehistoric pottery, burnt clay or plaster was found, which leads us to the assumption that one or more prehistoric objects can be presumed in this part of the site.

Of all the prehistoric finds ( 743 pieces), we studied in more detail 24 of them. Pottery was studied from technological and typological point of view. We've found that pottery is made in uniform manner and hand made. Most of it is fine-grained (79\%), the rest are very fine-grained (2I \%). We've found out eight different clay admixtures (LM). They represent mixed combination of rock (A), that doesn't react with HCI solution, mica (C), organic material (D), iron oxides (E), grog $(G)$ and/ or clay pellets $(\mathrm{F})$. There is no calcium carbonate (B). Most of the surface treatment is burnishing ( $96 \%$ or 23 pieces). We've recognized three types of firing techniques, reduction ( 17 pieces or $71 \%$ ), incomplete oxidation ( 5 pieces or $21 \%$ ) and reduction with oxidation in final phase ( 2 pieces or $8 \%$ ). Pottery is very (II pieces or. $46 \%$ ) or extraordinarily hard ( 12 pieces or. $50 \%$ ). Types of vessels are very united. Most of the pieces belong to pots or parts of them, as handles, lugs and decorated vessel. Two pieces belong to bigger (storage) pot (Figure 7). Both technological and typological ceramic analysis indicates the time of the Early and/or Middle Bronze Age. We've found analogies in the Vipava valley, in the Ljubljana basin, in Gulf of Trieste (cave sites and hillforts) and in Istria.

Archaeological excavations conducted at the Ključ site in 2014 showed that this is the type of the settlement that wasn't yet known in the Rižana valley or under the Karst Edge. We believe that Ključ site represents unfortified settlement on unexposed location. It is a type of settlement, as we know in Istria, Dalmatia and Herzegovina under the term hillfort in the open area. The function of this kind of settlements we can only presume, although for the moment the only explanations seems to be seasonal settlement type. So far, this is the only known kind of settlement from Early Bronze Age in this area. In close vicinity of the Ključ and the entire Rižana valley and under the Karst Edge we know only one contemporaneous site, the cave site Jama nad Brežcem. In our opinion, such a small number of Early Bronze Age sites in this area is only a consequence of the state of research.

\section{Literatura}

Batović, Š. 1990. »Novija istraživanja prapovijesti u biogradskom kraju «. Biogradski zbornik I: 85-195.

Benussi, B. 1927-1928. »Dalle annotazioni di Alberto Puschi per la Carta archeologica dell'Istria.« Archaeolografo Triestino I4: 243-82.

Bratina, P. 2014a. »Zemono pri Vipavi.«V Absolutno datiranje bronaste in železne dobe na Slovenskem / Absolute dating of Bronze and Iron Ages in Slovenia. Katalogi in monografije 40, uredila B. Teržan in M. Črešnar, 563-69. Ljubljana: Znanstvena založba Filozofske fakultete, Narodni muzej.

Bratina, P. 2014b. »Log pri Vipavi.«V Absolutno datiranje bronaste in železne dobe na Slovenskem / Absolute dating of Bronze and Iron Ages in Slovenia. Katalogi in monografije 4O, uredila B. Teržan in M. Črešnar, 569-8I. Ljubljana: Znanstvena založba Filozofske fakultete, Narodni muzej.

Buršić Matijašić, K. 1998. Gradina Monkodonja. Tipološko-statistička obrada keramičkih nalaza srednjebrončanodobne istarske gradine Monkodonja kod Rovinja / The Monkodonja Hillfort. A Typological and Statistical Analysis of Pottery Finds from the Middle Bronze Age Hillfort of Monkodonja near Rovinj. Monografije i katalozi 9. Pula: Arheološki muzej Istre.

Buršić Matijašić, K. 20II. »Ne samo gradine.« Histria Antiqua 20: 63-76.

Čović, B. 1983. »Regionalne grupe ranog bronzanog doba.« V Praistorija jugoslavenskih zemalja IV - Bronzano doba, 
uredil A. Benac, II 4־90. Sarajevo: Svjetlost: Akademija nauka i umjetnosti Bosne i Hercegovine.

Čović, B. 1989. »Posuška kultura.« Glasnik Zemaljskog muzeja BiH, n. s. 44: 6I-I27.

Čuka, M. 2009. »Tipološka obrada ulomaka prapovijesne keramike iz Pećine kod sela Srđani.« Histria archaeologica 40: 13-44.

Draksler, M., in R. Klasinc. 2014. »Arheološke raziskave na najdišcu Hrastovlje - Park avtohtonih živali.« Končno strokovno poročilo o raziskavi. Neobjavljeno poročilo. Ljubljana: Skupina STIK.

Hänsel, B., K. Mihovilić, in B. Teržan. 2015. Monkodonja. Istraživanja protourbanog naselja brončanog doba Istre. Knjiga I. Iskopavanje i nalazi gradevina / Monkodonja. Forschungen zu einer protourbanen Siedlung der Bronzezeit Istriens. Teil I. Die Grabung und der Baubefund. Monografije i katalozi / Monographien und Kataloge 25. Pula: Arheološki muzej Istre.

Hellmuth Kramberger, A. 2017a. Monkodonja: istraživanje protourbanog naselja brončanog doba Istre. Brončanodobna keramika s gradine Monkodonja / Forschungen zu einer protourbanen Siedlung der Bronzezeit Istriens. Die Keramik aus der bronzezeitlichen Gradina Monkodonja. Monografije i katalozi / Monographien und Kataloge 28. Knjiga / Teil 2/r, Tekst. Pula: Arheološki muzej Pula.

Hellmuth Kramberger, A. 2017 b. Monkodonja: istraživanje protourbanog naselja brončanog doba Istre. Brončanodobna keramika s gradine Monkodonja / Forschungen zu einer protourbanen Siedlung der Bronzezeit Istriens. Die Keramik aus der bronzezeitlichen Gradina Monkodonja. Monografije i katalozi / Monographien und Kataloge 28. Knjiga / Teil 2/2, Katalog. Pula: Arheološki muzej Pula.

Horvat, M. 1999. Keramika: tehnologija keramike, tipologija lončenine, keramični arhiv. Razprave Filozofske fakultete.
Ljubljana: Znanstveni inštitut Filozofske fakultete.

Fabec, T., in M. Vinazza. 2018. »Tomaj: Gradišče in Tabor. Poskus prepoznavanja dinamik preoblikovanja tomajskega griča od prazgodovine do danes.« Goriški letnik 42: $13-49$.

Gaspari, A. 2008. »Bronastodobno kolišče Mati Otavnik na Ljubljanskem barju.« Arheološki vestnik 59: 57-89.

Gili, E. in E. Montagnari Kokelj. 1992 (1993). >La grotta dei Ciclami nel Carso Triestino (materiali degli scavi 1959-196I).«Atti della società per la preistoria e protostoria della regione Friuli-Venezia Giulia VII: 65-162.

Gorenc, N. 2006. Gradovi, utrdbe in mestna obzidja. Vodnik po spomenikih. Zbirka Dnevi evropske kulturne dediščine. Ljubljana: Zavod za varstvo kulturne dediščine Slovenije.

Josipovič, D., M. Stokin in J. Horvat. 1997. »Sonde.«V Sermin. Prazgodovinska in zgodnjerimska naselbina $v$ severozahodni Istri / A Prehistoric and Early Roman Settlement in Northwestern Istria. Opera Instituti archaeologici Sloveniae 3, uredila J. Horvat, 22-29. Ljubljana: ZRC SAZU. Mihovilić, K. 2007-2008. »Gropi-Stari Guran. Analiza prapovijesne keramike.« Histria archaeologica 38-39: 37-79.

Register kulturne dediščine RS:

http://giskd6s.situla.org/giskd/ (dostop: I. 7. 2018).

Lonza, B. 1981. La ceramica del castelliere degli Elleri. Società per la preistoria e protostoria della Regione Friuli-Venezia Giulia, Quaderno 4. Trieste: Italo Svevo.

Sakara Sučević, M. 2004. »Arheološko gradivo iz jame nad Brežcem št. 5415 pri Podgorju, občina Koper.«Annales 14-2: 229-42.

Svetličič, V. 1997. »Prazgodovina / Prehistory.《 V Sermin. Prazgodovinska in zgodnjerimska naselbina v severozahodni Istri I A Prehistoric and Early Roman Settlement 
in Northwestern Istria. Opera Instituti archaeologici Sloveniae 3, uredila J. Horvat, II3-16. Ljubljana: ZRC SAZU.

Svoljšak, D. 1988-1989. »Posočje v bronasti dobi.« Arheološki vestnik 39-40: 367-86.

Šinkovec, I. 1995. »Katalog posameznih kovinskih najdb bakrene in bronaste dobe / Catalogue of Individual Metal Finds from the Eneolithic and Bronze Age. V Depojske in posamezne kovinske najdbe bakrene in bronaste dobe na Slovenskem I 1 Hoards and Individual Metal Finds from the Eneolithic and Bronze Ages in Slovenia I, uredila B. Teržan, 29-I27. Katalogi in monografije 29. Ljubljana: Narodni muzej Slovenija.

Šiškovič, R. 1990. »Prirodno-geografski oris in rast prebivalstva.« V Kraški rob in Bržanija. Zbornik ob soo-letnicifresk v Hrastovljah, 9-19. Koper: Pokrajinski muzej Koper.

Zupančič, M. 1990. »Arheološka podoba Brega s Kraškim robom.« V Kraški rob in Bržanija. Zbornik ob soo-letnici fresk $v$ Hrastovljah, 19-27. Koper: Pokrajinski muzej Koper.

Truhlar, F. 1975. »Hrastovlje.« V Arheološka najdišča Slovenije, I29. Ljubljana: Ljudska pravica.

Zendron, F. 2017. »In cammino verso la storia. I manufatti dell'età del Bronzo e dell'età del Ferro.«V Monte Castellier. Le pietre di Elleri narrano la storia, uredili P. Maggi, F. Pieri in P. Ventura 209-51. Triste: EUT. 